\title{
Az óriás útifü (Plantago maxima Juss. ex Jacq.) ex situ védelembe vonása II. Élöhelypreferencia-vizsgálat
}

\author{
KOVÁCS Zsófia ${ }^{1}$, BARABÁS Sándor ${ }^{2}$, CSONTOS Péter ${ }^{3}$, HÖHN Mária ${ }^{4}$ és \\ HONFI Péter ${ }^{5}$
}

${ }^{1,4}$ Szent István Egyetem, Növénytani Tanszék és Soroksári Botanikus Kert, 1118 Budapest, Villányi út 29-43.; ${ }^{1}$ zsofia.kovacs42@gmail.com;

4hohn.maria@kertk.szie.hu

${ }^{2}$ Ökológiai Kutatóközpont, ÖBI Terresztris Ökológiai Osztály,

2163 Vácrátót, Alkotmány u. 2-4.; kanyisa@freemail.hu,

${ }^{3}$ Agrártudományi Kutatóközpont, Talajtani és Agrokémiai Intézet, Talajbiológiai

Osztály, 1022 Budapest, Herman Ottó út 15.; csontos.peter@agrar.mta.hu

${ }^{5}$ Szent István Egyetem, Dísznövénytermesztési és Dendrológiai Tanszék,

1118 Budapest, Villányi út 29-43.; honfi.peter@kertk.szie.hu

Elfogadva: 2019. szeptember 16.

Kulcsszavak: ex situ, fajmegőrzés, konzervációbiológia, morfometria, peroxidáz enzim.

Összefoglalás: Munkánk az óriás útifü (Plantago maxima Juss. ex Jacq.) ex situ védelmét és fenntartását célozza. Kutatásunk elöző szakaszában az óriás útifü csírázásbiológiáját tanulmányoztuk, vizsgálva a hidegkezelés és a fény szerepét, valamint a magméret hatását és az egyedek csírázási tulajdonságait. A szaporítási kísérletből származó növényekből 2016 tavaszán ex situ állományokat létesítettünk a faj gyüjteményeskerti megőrzése és élőhelyi igényeinek felmérése céljából. Az ex situ állományokat a Soroksári Botanikus Kert kékperjés láprétjén, három különböző vízellátottságú területen hoztuk létre, így lehetőségünk volt vizsgálni a populációk eltérő élőhelyi adottságokra adott válaszát. Két olyan ex situ állományt is létesítettünk, amelyeknél rendszeres kertészeti fenntartást biztosítottunk (gyommentesség, öntözés): egyet a Soroksári Botanikus Kert alföldi tava mellett, egyet pedig a Budai Arborétum évelöágyában. A vizsgálatok során a növények fejlődését két éven keresztül (2016-2017-ben) morfometriai mérésekkel követtük nyomon. A 2017-es évben felmértük a túlélési arányt is. A kékperjés lápréti élőhelyek pontosabb jellemzésére fajlistát készítettünk. A peroxidázenzim-aktivitás vizsgálatával támasztottuk alá morfometriai méréseink fiziológiai hátterét. Eredményeink alapján megállapítottuk, hogy az egyedek számára optimálisnak a lápréti állományok közül a mezofil élőhely bizonyult, ahol kielégítően fejlödtek az egyedek, magas volt a túlélési arány, és az innen gyüjtött növényi mintákban alacsony volt a peroxidázenzim-aktivitás. A higrofil és sztyeppei állományban a növekmény szignifikánsan kisebb volt. A kertészetileg fenntartott két állományban azt tapasztaltuk, hogy a növények már a kitelepítés évében generatív fázisba léptek, ami a kétéves vizsgálat során a többi állományban elmaradt. A morfometriai mérések alapján ezekben a kertészetileg fenntartott állományokban mértük a legnagyobb növekményt is. 


\section{Bevezetés}

Az óriás útifü (Plantago maxima Juss. ex Jacq.) a Turjánvidék fokozottan védett növénye. A korábban már kihaltnak vélt faj közel 40 év „lappangás” után került elő újra Magyarországon (FARKAS 1990, VidÉKi és MÁTÉ 2003). A legmagasabb kiszabható természetvédelmi értékü faj (250 000 Ft; 13/2001. (V.9.) KöM rendelet). Jelenleg ismert állományai a Duna-Ipoly Nemzeti Park Igazgatóság (Kakucs, Táborfalvai Lő- és Gyakorlótér, Tatárszentgyörgy) és a Kiskunsági Nemzeti Park Igazgatóság (Kunpeszéri Szalag-erdő) területén találhatók (1. ábra). Az állományok igen különböző méretűek, a legnagyobb (2000 tövet meghaladó) a Kunpeszéri Szalag-erdőnél található. Hazánkban a faj egyedszáma 2500 tőre becsülhető. Állományai erősen fragmentáltak és egymástól, valamint a kontinuus areán lévő populációktól is izoláltak. Irodalmi adatok szerint Bulgáriában és Romániában találhatók a legközelebbi óriás útifú állományok, ezek azonban még a diszjunkt areájú faj peremi területein elhelyezkedő fragmentumok. Az öszszefüggő area nagyjából Nyugat-Szibériától és a Kazah-hátságtól kezdődik.

Ahogyan a neve is sugallja, az óriás útifü nagytermetü, erőteljes növekedésű, 60-100(-120) cm magas, tőlevélrózsás évelő (hemikriptofiton) faj, vastag, erős főgyökérzettel (VIDÉKI és MÁTÉ 2003). Levelei bőrneműek, tőállók, húsos tapintásúak és felállók, szélesek vagy hosszúkás-tojásdadok, 10-30 cm hosszúak és

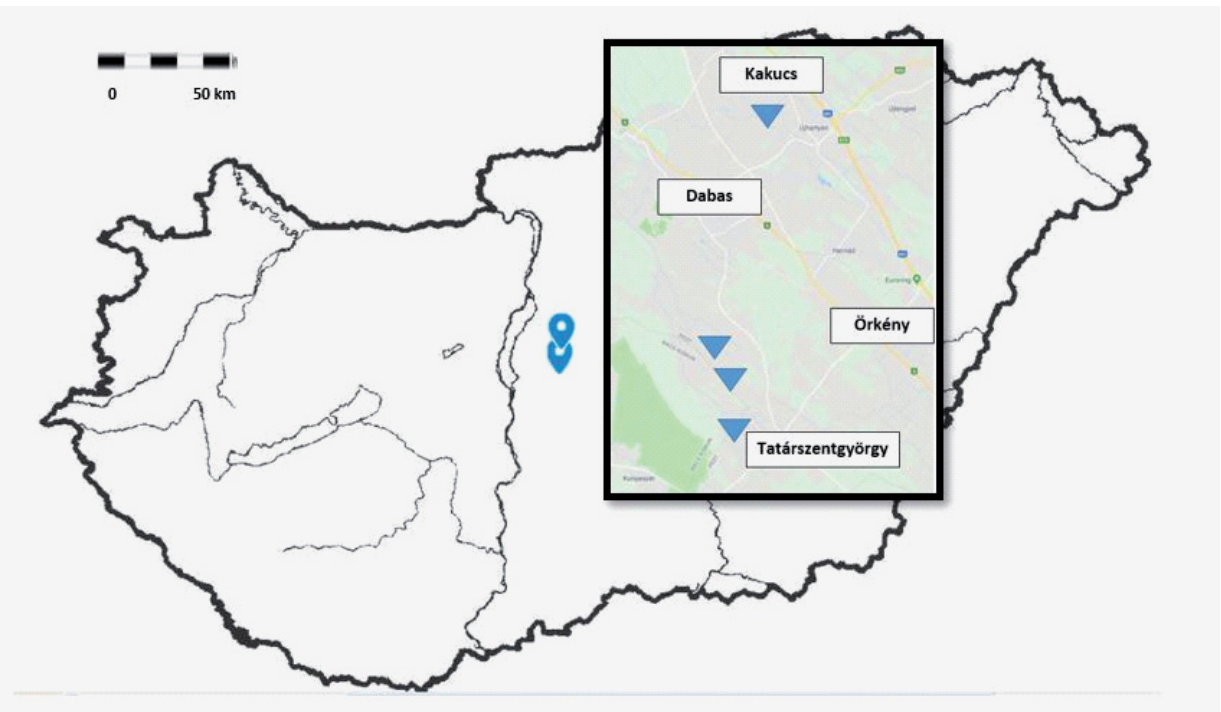

1. ábra. Az óriás útifü (Plantago maxima Juss. ex Jacq.) hazai állományainak földrajzi helyzete. A populációk lelőhelyét a háromszögek jelzik.

Fig. 1. Localities of giant plantain (Plantago maxima Juss. ex Jacq.) populations in Hungary. Triangles indicate the population localities. 
5-15 cm szélesek, 9(-11) erüek. A levél hossza fele a tőkocsányénak, a levélnyél általában hosszabb a levéllemeznél, csatornás és kívülről rovátkolt. Mindezek fontos határozóbélyegek, melyek alapján a rokon fajoktól jól elkülöníthető (Simon 2000, Király 2009). A tőkocsány egyenesen álló, hengeres, és akárcsak a levélnyél, feltűnően barázdált, valamint finom szőrözöttség jellemzi (VIDÉKI és Máté 2003). A virágzat $5-15(-20) \mathrm{cm}$ hosszú tömött füzérvirágzat. A füzér hossza a tőkocsány hosszúságának az 1/3-át nem haladja meg. A párta lehet fehér vagy fehéres-rózsaszín, ami a virágzat jellegzetes krémszínét adja. A porzószálak fehér színűek, és jelentős mértékben kinyúlnak a virágokból. Nyáron virágzik, június-augusztus között. Termése toktermés, melyben 4 mag található. A magok 3-4 mm hosszúak és hosszúkás-elliptikusak (FARKAs 1999, Simon 2000, VidÉKI és Máté 2003, TzONEV és KARAKIEV 2007, Király 2009).

Az óriás útifü preferálja a vályogos, pangóvizes élőhelyeket, állományai mocsaras területeken és lápréteken fordulnak elő. Cönológiai vizsgálatok szerint Succiso-Molinietum hungaricae (Komlódi 1958) Soó 1969 corr. Borhidi 2001 társuláshoz sorolható faj (Soó 1968, VidéKi és MÁTÉ 2003, Tzonev és KARAKIEv 2007). Bulgáriai állománya az Európai Unió 62/43-as irányelve szerint szintén Molinion lápréthez kötődik (Tzonev és Karakiev 2007, European Commission DG ENVironMENT 2013). Az eurázsiai elterjedésủ faj az area belső részein már halofil jellegü, sztyeppesedő gyepekben jelenik meg (FrASER és KEDDY 2005).

A peroxidázenzim (POD) a növényi szövetekben a kloroplasztiszokban, a citoplazmában és a sejtfalban található meg (LÁNG 2002). Növényélettani szerepe sokrétű, elsődlegesen a hidrogén-peroxid semlegesítése és az elektrondonorok oxidált termékeinek elöállítása a cél (AsADA 1992). Biotikus és abiotikus stressz hatására az enzim szintje megnövekszik, így nő a növény védekező képessége, és ezáltal fokozódik a stresszel szembeni ellenállóképessége. Ilyen abiotikus stresszor lehet a túl sok vagy túl kevés víz, a sóstressz, a magas besugárzás előidézte stressz, ami fokozott lipidperoxidációval és magasabb POD aktivitással jellemezhető (REIG et al. 2013). A peroxidázenzim aktivitásának meghatározása a stressztényezők felmérésére, így az élőhelyoptimum meghatározására is használható.

Az óriás útifü ex situ védelembe vonása rendkívüli módon indokolt, mert a faj fennmaradását a termőhely kiszáradása és inváziós fajok terjedése erősen veszélyezteti. Fontos még kiemelni, hogy a hazai állományok areaperemi, marginális populációk, amelyekből három állomány összegyedszáma 300 tőre becsülhető. Élőhelyét gyakran borítja el az erőteljes polikormonképző kanadai aranyveszszö (Solidago canadensis L., BotTA-DUKÁt és DANCZA 2004). További probléma a Táborfalvai Lö- és Gyakorlótéren, hogy az aktív lőgyakorlatok miatt fokozott tüzveszéllyel kell számolni (MOLNÁR-BAJI 2013).

Kutatásunk célja az ex situ állományok kialakításán és fenntartásán túl, a faj élőhelyi igényeinek megismerése és a repatriáláshoz szükséges ismeretek bővíté- 
se. Munkánk első részében a csírázásbiológiai preferenciát vizsgáltuk (KovÁcs et al. 2018). Az ex situ állományok létesítését és az élőhelyi preferencia vizsgálatát jelen cikkünkben tárgyaljuk.

\section{Anyag és módszer}

A csírázásbiológiai kísérletek folytatásaként 2016 tavaszán a palántákból három, egyenként 100 töves ex situ állományt létesítettünk a Szent István Egyetem Kertészettudományi Karához tartozó Soroksári Botanikus Kert kékperjés láprétjén, amely az óriás útifü hazai előfordulásához hasonló fajkészletű természetes élőhely. A Soroksári Botanikus Kertben található pannon kiszáradó láprét 12 ha területű, meszes talajú, fragmentálódott gyep (HöH 2013). A Duna-Tisza közére jellemző eredeti növénytársulás (Succiso-Molinietum) az óriás útifü élőhelyének cönológiai viszonyaihoz hasonlít a hazai és nemzetközi irodalom alapján is (Soó 1968, VidéKi és MÁté 2003, Tzonev és KARAKIEv 2007). A soroksári láprét természetközeli állapotának hosszú távú megőrzéséhez hozzájárult a megfelelő időben végzett kaszálás, az inváziós gyomnövények visszaszorítása (HöHN 2013), ami az óriás útifü természetes állományaiban is fontos természetvédelmi kezelés. Az óriás útifü állományokat eltérő vízellátottságú kékperjés lápréti termőhelyekre telepítettük: 1. higrofil - tavasszal pár hónapig tartós vízborítással rendelkező terület; 2 . mezofil - tavaszi kis mértékü és rövid ideig tartó vízborítású terület, és 3. sztyeppei jellegü terület, ahol tavasszal sem tapasztalható vízborítás, és számottevő az inváziós fajok jelenléte (Symphyotrichum sp., Solidago spp.). Az eltérő hidrológiai viszonyok lehetővé teszik a faj tartós vízborítással szembeni toleranciájának vizsgálatát, valamint kompetíciós képességének megfigyelését. További két, kertészeti fenntartású állományt is létrehoztunk, egy 3 töves állományt a Soroksári Botanikus Kert kerti tava mellett, és egy 5 tőből álló állományt a Budai Arborétum évelőágyában, melyeket elsősorban bemutató jellegü telepítésnek szántunk. Az ágyások többfunkciós használata miatt indokolt volt, hogy ezekre a helyekre csak viszonylag kevés egyedet ültessünk ki.

Az öt állományban két éven keresztül (2016. május 9. és augusztus 16., valamint 2017. május 9. és augusztus 15. között) végeztünk morfometriai méréseket. Mérőszalag segítségével megmértük 68 példányon a legnagyobb és egy közepes méretű, átlagos levél hosszát (levéllemez és levélnyél együttes mérése) és szélességét, megszámláltuk a tőlevélrózsában fejlesztett levelek számát, és abban az esetben, ha a vizsgált tő hozott virágzati szárat, megszámoltuk azok darabszámát is. Az első év után, 2017. június 9-én felmértük a túlélési arányt a kiültetett állományokban.

Az állományok betelepítésére használt természetközeli élőhelyek jellemzésére 2017. július 7-én összeírtuk a három pannon kékperjés lápréti állomány 
növényfajait. Minden állományban $5 \mathrm{db} 1 \mathrm{~m}^{2}$-es kvadrátot jelöltünk ki, majd a kvadráton belül található növényeket faji szinten meghatároztuk. Megvizsgáltuk, hogy egy faj hány kvadrátban fordult elő az adott állományon belül, azaz a fajok frekvenciaadatait számítottuk ki. A cél az volt, hogy a területen élö növényfajok ismeretében a termőhely állapotára vonatkozóan pontosabb megállapításokat tehessünk. A fajokhoz ezután hozzárendeltük a Borhidi-féle ökológiai indikátor-értékek közül a megfelelő talajnedvesség (WB), talajreakció (RB), relatív nitrogénigény ( $\mathrm{NB}$ ) és sótürés, ill. sókedvelés $(\mathrm{SB})$ értékeket, valamint a szociális magatartás típusokat (BORHIDI 1993, HoRVÁTH et al. 1995).

Az élőhely preferencia megfigyelések fiziológiai hátterének vizsgálatára peroxidázenzim-aktivitás spektrofotometriás meghatározását végeztük el. A mintavétel során minden állományból 3 különböző egyedről, összesen $3 \mathrm{db}$ levelet gyüjtöttünk 2017. szeptember 12-én. A vizsgálatokat 2017. szeptember 21-én végeztük el. Az alkalmazott protokoll első lépése a kivonatkészítés. Mintánként kb. 200 mg növényi részt (levelet) használtunk fel. A minták pontos tömegét analitikai mérleggel határoztuk meg. A mintákat homogenizáltuk jéghideg dörzsmozsárban, késhegynyi kvarchomok hozzáadásával. Az eldörzsöléshez mintánként $1200 \mu \mathrm{l} \mathrm{K}$-foszfát puffer oldatot $(\mathrm{pH}=6,5)$ használtunk fel, melyet a homogenizálás közben apránként adagoltunk. Dörzsölés után 2 ml-es centrifugacsőbe töltöttük a homogenizált kivonatot. A kimért kivonatokat jég között tároltuk az enzim elbomlásának meggátolása érdekében. A mintákat hütött centrifugában $4{ }^{\circ} \mathrm{C}$-on, percenként 13500 fordulatszámon, 20 percig centrifugáltuk (Eppendorf Centrifuge 5418R). Tömény (30\%-os) hidrogén-peroxidból százszoros hígítású vizes oldatot készítettünk az alábbiak szerint: $50 \mu \mathrm{l} \mathrm{H}_{2} \mathrm{O}_{2}+4950 \mu \mathrm{l}$ desztillált víz. A méréshez 4,5 pH-értékủ Naacetát puffert használtunk (Na-acetát-oldat és ecetsav elegye). Az ortodianizidint metanolban hígítottuk $10 \mathrm{mg} / \mathrm{ml}$ töménységüre. A mérést műanyag küvettákban végeztük. Az első mérést vakmintán végeztük $460 \mathrm{~nm}$-en: $1800 \mu \mathrm{l} \mathrm{Na-acetát} \mathrm{puffer}$ $+30 \mu \mathrm{l}$ 0,3\%-os $\mathrm{H}_{2} \mathrm{O}_{2}+20 \mu$ ortodianizidin használtunk fel. Ezután a többi mérés során az elegyhez a növényi mintákat is hozzákevertük, az alábbiak szerint: $1700 \mu \mathrm{l}$ puffer $+30 \mu \mathrm{l}$ 0,3\%-os $\mathrm{H}_{2} \mathrm{O}_{2}+20 \mu$ l ortodianizidin $+100 \mu \mathrm{l}$ a növényi kivonatból $=$ $1850 \mu \mathrm{l}$ összesen. Parafilmet tettünk a küvetták tetejére és 1-2-szer megfordítottuk a jobb elegyedés érdekében. A spektrofotométer (Varian DMS 100 UV-VIS) 10 másodpercenként mérte a fényelnyelést. A minta fényelnyelését a program $460 \mathrm{~nm}$-en mérte, az enzimaktivitást az alábbi képlet alapján számítottuk ki:

$$
\text { enzimaktivitás }=(\Delta \mathrm{A} 1 \cdot \text { hígulás }) / \varepsilon[\mathrm{unit} / \mathrm{ml}]
$$

ahol: $\Delta \mathrm{A} 1: 1$ perc alatti abszorbancia-változás; $\varepsilon=11,3$ : az ortodianizidin extinkciós koefficiense (a színváltozás mértékét jellemzi).

Az így kapott értéket unit/mg-ra számítottuk ki, így megkaptuk a tömegre vetített értékeket. 
A morfometriai mérések statisztikai értékeléséhez MANOVA modellt alkalmaztunk. A hibatagokra vonatkozó normalitást a ferdeség (abszolútérték < 1) és csúcsosság (abszolútérték < 1 ) alapján fogadtuk el, a levélszámokat $-1 /(\sqrt{ } \mathrm{x})$ transzformációval és egy kiugró érték eltávolításával normalizáltuk. A hibatagok szóráshomogenitását a Levene-teszttel ellenőriztük. A szignifikáns különbségeket post hoc teszttel tártuk fel. A szóráshomogenitás a levélszám esetében teljesült, itt Tukey-féle tesztet alkalmaztunk. Minden más esetben a szórásinhomogenitást jól kezelő Games-Howel post hoc tesztet futtattuk. A peroxidázenzim-aktivitás és a szociális magatartás típusok esetében az eredményeket egytényezős ANOVA modellel értékeltük. Szignifikáns különbséget $\mathrm{p}<0,05$ esetén fogadtunk el. A statisztikai értékelésekhez az IBM SPSS Statistics 23 programot használtuk.

\section{Eredmények}

A morfometriai mérések összesített eredményét a 2. ábra foglalja össze. Az első szempont a legnagyobb levélhossz-értékek összehasonlítása volt. A mérések szerint a 2016-os évben a kékperjésbe telepített állományok közül a mezofil állomány értéke szignifikánsan nagyobb volt a higrofil állományban mértnél, ez a különbség a 2017-es évben nem volt tapasztalható, viszont ekkor a sztyeppei jellegü állomány különült el szignifikánsan nagyobb értékkel a másik két kékperjésben élő állománytól. A két kertészetileg fenntartott állomány, azaz a Budai Arborétum évelőágyásába, illetve a Soroksári tó mellé telepített egyedek 2016-ban szignifikánsan nagyobbak voltak a többi állományhoz képest, míg a 2017-es évben a Budai Arborétum állományánál volt tapasztalható ez a nagyobb növekmény.

$\mathrm{Az}$ átlagos levélhossz tekintetében a kékperjésben élő állományok között a 2016-os évben a mezofil állomány szignifikánsan nagyobb értéket mutatott a

2. ábra. A morfometriai változók alakulása a Plantago maxima különböző élőhelyre telepített ex situ állományaiban. Az oszlopok mintázata (telt és sávozott) a fenntartás szempontjából eltérő állományokat jelöli. Telt oszlopok: természetközeli élőhelyre telepített állományok, sávozott oszlopok: kertészetileg gondozott állományok. $\mathrm{A}=$ legnagyobb levélhossz; $\mathrm{B}=$ átlagos levélhossz; $\mathrm{C}=$ legnagyobb levélszélesség; $\mathrm{D}$ = átlagos levélszélesség; $\mathrm{E}$ = tövenkénti levélszám. A szóráspálcikák \pm 1 szórást mutatnak, eltérő kisbetűk az oszlopok felett szignifikáns különbséget jeleznek $(\mathrm{p}<0,05)$. Fig. 2. Morfometric characters of the studied Plantago maxima ex situ populations in different habitats. The different pattern of the columns show different populations according to maintenance. Full columns: close-to-natural conditions (from left to right: hygrophilous, mesophilous and steppic habitat), striped columns: horticultural maintainance. $\mathrm{A}=$ length of the largest leaf; $\mathrm{B}=$ average leaf length; $\mathrm{C}=$ width of the largest leaf; $\mathrm{D}=$ average leaf width; $\mathrm{E}=$ number of leaves. Columns from left to right are different ex situ stands: higrophylous, mesophylous, steppic, Budai Arboretum, Soroksár Botanical Garden pond site. Error bars show $\pm 1 \mathrm{SD}$, different lower case letters above columns indicate significant difference $(\mathrm{p}<0.05)$. 
A

2016

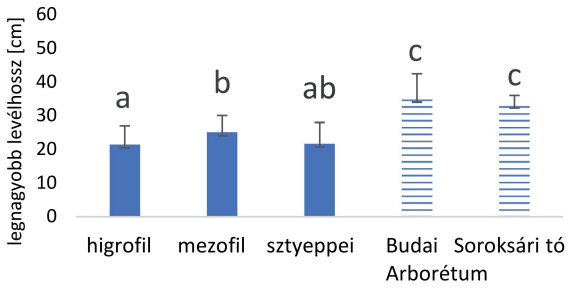

B

2016

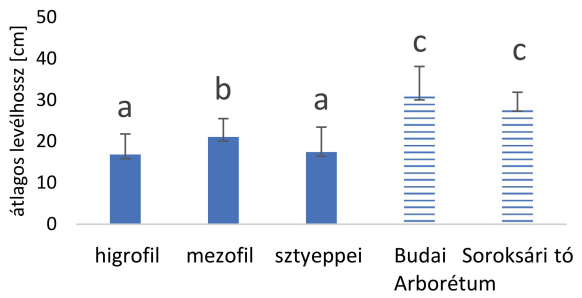

C

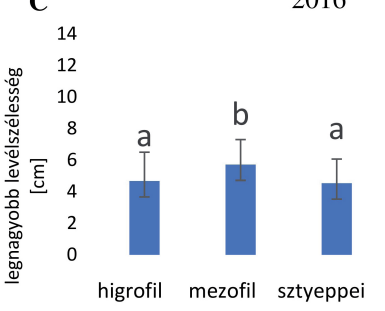

D

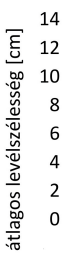

higrofil mezofil sztyeppe
2016

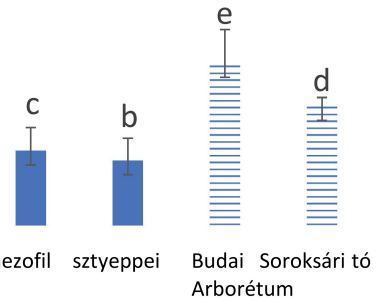

2016

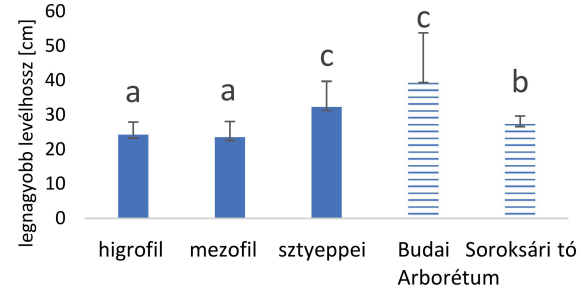

2017

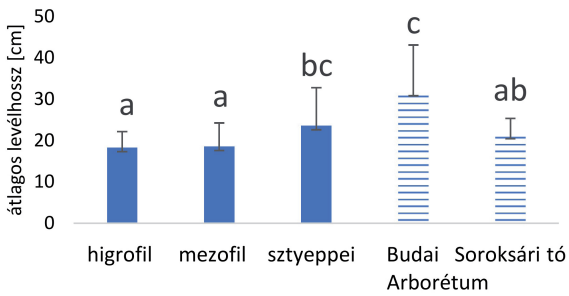

2017

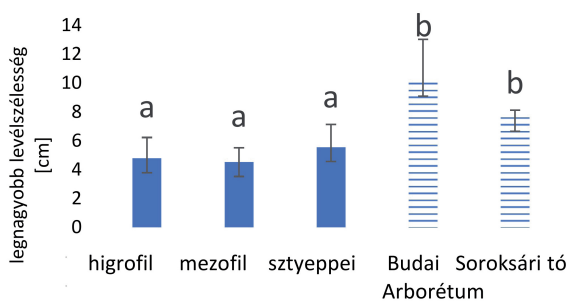

2017

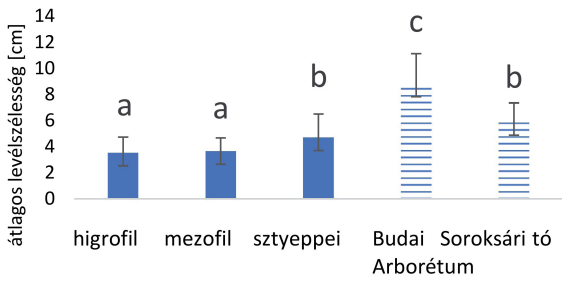

2017

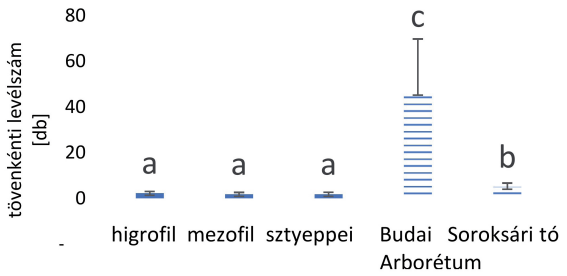


higrofil és sztyeppei állományhoz képest, viszont 2017-ben a sztyeppei állomány volt szignifikánsan magasabb értékü a másik két állományhoz viszonyítva ( $2 \mathrm{~B}$ ábra). A kertészetileg fenntartott állományok közül a Budai Arborétum évelőágyában élő egyedek mindkét évben, a Soroksári tó mellettiek 2016-ban szignifikánsan nagyobb átlagos levélhosszal jellemezhetőek, mint a lápréti állományok. A legnagyobb növekmény mindvégig a Budai Arborétum egyedeit jellemezte.

A legnagyobb levélszélesség esetében 2016-ban a mezofil állomány különült el szignifikánsan nagyobb értékkel a lápréti állományokon belül, ez a különbség 2017-ben nem volt kimutatható (2C ábra). A kertészetileg fenntartott állományok ebben az esetben is szignifikánsan magasabb értékeket mutattak a lápréti állományokhoz képest.

Az átlagos levélszélesség esetén 2016-ban minden állomány szignifikánsan elkülönült egymástól, a lápréten a legmagasabb értéket a mezofil, a legalacsonyabbat a higrofil állomány mutatta (2D ábra). 2017-ben a lápréti állományok közül a sztyeppei különült el szignifikánsan nagyobb növekménnyel. A kertészetileg fenntartott állományok közül a Budai Arborétum egyedei szignifikánsan magasabb értéket mutattak a többi állományhoz képest.

A levélszám tekintetében a két év során hasonló értékeket kaptunk (2E ábra). A természetközeli élőhelyre telepített állományok között nem tapasztaltunk szignifikáns eltérést, ugyanakkor ezek szignifikánsan kisebb értékekkel (átlagosan 2-3 db levél) elkülönültek a kertészetileg fenntartott állományoktól. A Soroksári tó melletti tövek esetében átlagosan 5-7 db, a Budai Arborétum egyedeinél pedig $40 \mathrm{db}$-nál is több levél fejlődött.

Összességében elmondható, hogy a kertészetileg fenntartott állományok egyedeinek növekményei szinte minden mutató esetében szignifikánsan magasabb értékkel tértek el a három lápréti állomány egyedeitől. A legnagyobb értékeket a Budai Arborétum évelőágyában lévő egyedek esetében tapasztaltuk. A vizsgálatok további eredménye, hogy a két év során generatív fázisba csak a kertészetileg fenntartott tövek jutottak, a lápréti állományokban elmaradt a virágzás. A virágzati kezdemények megjelenése, a 2016-os és a 2017-es évben is április végétől volt megfigyelhető a Soroksári Botanikus Kert tó melletti és a Budai Arborétum évelőágyi állományai esetében. A virágzatok száma 2016-ban a soroksári tóhoz kiültetett egyedeknél 2 db, míg az arborétumi töveknél 30 db volt. 2017-ben Soroksáron 1 db, a Budai Arborétumban 15 db virágzat volt megfigyelhető.

A 2017-es évben a túlélési arány felmérése során a soroksári láprét esetében a higrofil állományban $36 \mathrm{db}$, a mezofil állományban $69 \mathrm{db}$, míg a sztyeppei állományban 64 db élő egyed volt jelen, ami 36, 69, illetve 64\%-os túlélési arányt jelentett az egyes állományokban. A Budai Arborétumban 2 egyed, és a Soroksári Botanikus kert alföldi tava melletti állománynál is 2 egyed maradt életben. 
A kékperjés lápréti élőhelyek fajkészlete a Borhidi-féle relatív talajvíz-, ill. talajnedvesség (WB-érték) alapján, ahogy azt előzetesen prognosztizáltuk, elkülönült egymástól. A higrofil állománynál elsősorban üde fajok, a mezofil állománynál átmeneti, míg a sztyeppei állomány esetében már mezo-xerofil és xerofil elemek is megjelentek (KovÁcs 2017). A talajreakció (RB-érték) alapján az élőhelyek jellemzően neutrális vagy gyengén baziklin, valamint mészkedvelő, ill. bazifil fajokkal jellemezhetőek. A relatív nitrogénigény (NB-érték) szempontjából elmondható, hogy a nitrogénellátottság tekintetében a sztyeppei élőhelyen volt a legtöbb nitrogénigényes faj, míg a sótűrés, illetve sókedvelés ( $\mathrm{SB}$ érték) alapján az állományokban felmért fajok túlnyomó többsége sókerülőnek mutatkozott (Kovács 2017). A szociális magatartás típusok (SBT) statisztikai értékelése során a sztyeppei állomány szignifikánsan kisebb értékkel elkülönült, amit részben az antropogén, tájidegen elemek nagyobb arányú előfordulása okozott (például Solidago canadensis L., Solidago gigantea Ait. subsp. serotina (Ait.) McNeill és a Symphyotrichum novae-angliae (L.) G. L. Nesom. A magasabb értéket a higrofil és mezofil állományokban a ritka, unikális fajok jelenléte eredményezte, mint például a Koeleria javorkae Ujhelyi, vagy a Gymnadenia conopsea (L.) R. Br. (3. ábra). A sztyeppei állomány mutatja a legnagyobb hasonlóságot az óriás útifü táborfalvai katonai lőtéri természetes élőhelyével, melynek fennmaradása veszélyeztetett, így az ex situ állomány értékelése megalapozhatja a helyszín kijelölését és a fenntartás mikéntjét. Az 1. táblázatban közöljük a három élőhelytípusban felvett kvadrátok növényfajait.

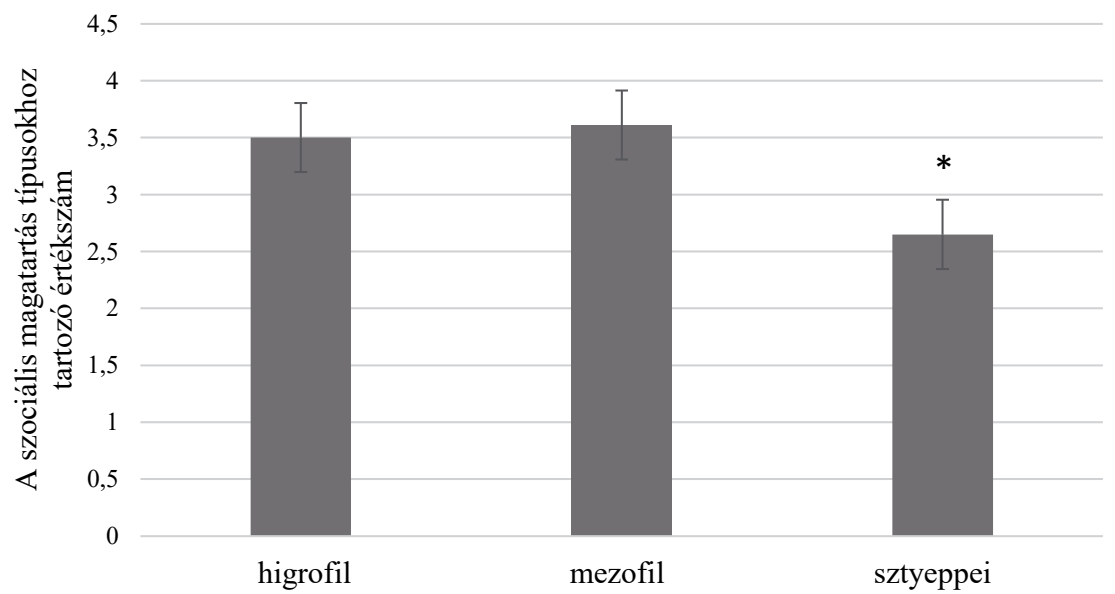

3. ábra. A fajkészlet értékelése szociális magatartás típusok szerint a három lápréti állományban. A szóráspálcikák \pm 1 szórást mutatnak, a csillag szignifikáns különbséget $(\mathrm{p}<0,05)$ jelez.

Fig. 3. Sums of Social Behavior Type values in the three fen meadow habitats (hygrophilous, mesophilous, steppic). Error bars show $\pm 1 \mathrm{SD}$, the asterisk indicate significant difference $(\mathrm{p}<0.05)$. 
1. táblázat. A kékperjés lápréti állományokban készült fajlista, a számok azt jelölik, hogy az öt kvadrátból hányban fordult elő a faj az állományokon belül (2017).

Table 1. The species list of the fen meadow. Numbers from 0 to 5 indicate the number of quadrates within a habitat where species were recorded (2017). (1) Species; (2) habitat (from left to right: hygrophilous, mesophilous, steppic).

\begin{tabular}{|c|c|c|c|}
\hline \multirow[t]{2}{*}{ Faj (1) } & \multicolumn{3}{|c|}{ Élőhely (2) } \\
\hline & higrofil & mezofil & sztyeppei \\
\hline Achillea asplenifolia Vent. & 1 & 3 & 1 \\
\hline Achillea collina J. Becker & 0 & 1 & 1 \\
\hline Agrostis stolonifera L. & 0 & 0 & 1 \\
\hline Agrostis capillaris $\mathrm{L}$. & 2 & 1 & 3 \\
\hline Allium scorodoprasum $\mathrm{L}$. & 0 & 1 & 2 \\
\hline Arrhenatherum elatius (L.) J. et C. Presl & 0 & 1 & 5 \\
\hline Briza media L. & 1 & 4 & 3 \\
\hline Calamagrostis epigeios (L.) Roth & 0 & 0 & 2 \\
\hline Carex acutiformis Ehrh. & 1 & 0 & 0 \\
\hline Carex flacca Schreb. & 1 & 4 & 2 \\
\hline Carex hostiana DC. & 1 & 0 & 0 \\
\hline Carexpanicea L. & 2 & 0 & 4 \\
\hline Carex tomentosa $\mathrm{L}$. & 0 & 5 & 1 \\
\hline Centaurea jacea L. & 3 & 4 & 0 \\
\hline Cirsium arvense (L.) Scop. & 1 & 0 & 4 \\
\hline Cirsium canum (L.) All. & 1 & 0 & 0 \\
\hline Colchicum autumnale $\mathrm{L}$. & 0 & 1 & 0 \\
\hline Dactylis glomerata L. s.str. & 0 & 2 & 3 \\
\hline Daucus carota L. subsp. carota & 0 & 1 & 3 \\
\hline Deschampsia caespitosa (L.) P. B. & 0 & 3 & 2 \\
\hline Deschampsia flexuosa (L.) Trin. & 5 & 0 & 0 \\
\hline Dorycnium pentaphyllum subsp. germanicum (Gremli) Gams & 0 & 4 & 3 \\
\hline Epilobium hirsutum $\mathrm{L}$. & 0 & 0 & 2 \\
\hline Equisetum arvense $\mathrm{L}$. & 3 & 2 & 1 \\
\hline Equisetum ramosissimum Desf. & 0 & 5 & 1 \\
\hline Eupatorium cannabinum $\mathrm{L}$. & 0 & 0 & 1 \\
\hline Festuca arundinacea Schreb. & 0 & 0 & 1 \\
\hline Festuca pratensis Huds. & 0 & 2 & 1 \\
\hline Frangula alnus Mill. & 0 & 0 & 4 \\
\hline Galium mollugo L. & 0 & 2 & 3 \\
\hline Galium verum $\mathrm{L}$. & 2 & 4 & 5 \\
\hline Genista tinctoria L. & 3 & 0 & 4 \\
\hline Gymnadenia conopsea (L.) R. Br. & 0 & 1 & 0 \\
\hline Holcus lanatus L. & 0 & 1 & 1 \\
\hline Inula salicina $\mathrm{L}$. & 0 & 1 & 0 \\
\hline
\end{tabular}


1. táblázat / Table 1 (folyt. / cont.)

\begin{tabular}{|c|c|c|c|}
\hline \multirow[t]{2}{*}{ Faj (1) } & \multicolumn{3}{|c|}{ Élőhely (2) } \\
\hline & higrofil & mezofil & sztyeppei \\
\hline Juncus atratus Krocker & 1 & 0 & 0 \\
\hline Koeleria javorkae Ujhelyi & 2 & 3 & 0 \\
\hline Lathyrus pratensis $\mathrm{L}$. & 2 & 0 & 0 \\
\hline Leucanthemum vulgare Lam. & 0 & 1 & 0 \\
\hline Linum catharticum $\mathrm{L}$. & 0 & 1 & 0 \\
\hline Lotus tenuis W. et $\mathrm{K}$. & 0 & 2 & 0 \\
\hline Lysimachia vulgaris $\mathrm{L}$. & 5 & 4 & 3 \\
\hline Lythrum salicaria L. & 2 & 0 & 2 \\
\hline Mentha aquatica $\mathrm{L}$. & 1 & 0 & 0 \\
\hline Molinia coerulea Mönch & 3 & 4 & 0 \\
\hline Ononis spinosa $\mathrm{L}$. & 0 & 1 & 3 \\
\hline Phragmites australis (Cav.) Trin. & 1 & 0 & 2 \\
\hline Picris hieracioides $\mathrm{L}$. & 0 & 0 & 1 \\
\hline Plantago lanceolata $\mathrm{L}$. & 0 & 0 & 1 \\
\hline Poa pratensis $\mathrm{L}$. & 0 & 1 & 1 \\
\hline Potentilla reptans $\mathrm{L}$. & 0 & 1 & 0 \\
\hline Prunella vulgaris $\mathrm{L}$. & 4 & 5 & 1 \\
\hline Pyrus pyraster Burgsd. & 0 & 2 & 0 \\
\hline Ranunculus acris $\mathrm{L}$. & 4 & 4 & 1 \\
\hline Ranunculus polyanthemos $\mathrm{L}$. & 0 & 1 & 2 \\
\hline Ranunculus repens $\mathrm{L}$. & 1 & 0 & 1 \\
\hline Rhinanthus minor $\mathrm{L}$. & 1 & 3 & 2 \\
\hline Rosa canina L. & 0 & 0 & 1 \\
\hline Rubus caesius $\mathrm{L}$. & 4 & 0 & 5 \\
\hline Rumex acetosa $\mathrm{L}$. & 0 & 1 & 2 \\
\hline Sanguisorba officinalis $\mathrm{L}$. & 1 & 5 & 4 \\
\hline Senecio erraticus Bert. subsp. barbareifolius (Willk. et Gr.) Beger & 0 & 2 & 2 \\
\hline Serratula tinctoria $\mathrm{L}$. & 2 & 4 & 0 \\
\hline Solidago canadensis $\mathrm{L}$. & 0 & 0 & 3 \\
\hline Solidago gigantea Ait. subsp. serotina (Ait.) McNeill & 0 & 0 & 2 \\
\hline Stachys officinalis $\mathrm{L}$. & 1 & 2 & 3 \\
\hline Succisa pratensis Mönch & 5 & 3 & 0 \\
\hline Symphyotrichum novae-angliae (L.) G. L. Nesom & 0 & 0 & 1 \\
\hline Symphytum officinale $\mathrm{L}$. & 0 & 0 & 3 \\
\hline Tetragonolobus maritimus (L.) Roth subsp. siliquosus (L.) Murb. & 0 & 2 & 0 \\
\hline Valeriana officinalis L. s. str. & 0 & 0 & 1 \\
\hline Vicia cracca $\mathrm{L}$. & 5 & 5 & 4 \\
\hline Vicia lathyroides $\mathrm{L}$. & 0 & 1 & 1 \\
\hline
\end{tabular}


A peroxidázenzim-aktivitás értékelése során a kékperjésbe telepített állományok közül a legmagasabb értéket az üde élőhelyen mértünk (4. ábra). Itt feltételezhetően nagyobb stresszhatásnak voltak kitéve az egyedek, amit az alacsonyabb túlélési érték is mutat. A természetközeli élőhelyre telepített állományok közül a mezofil élőhely tekinthető optimálisnak a faj számára. A kertészeti fenntartás is kedvezően hatott a növények fejlődésére, és ezzel együtt alacsony stresszenzim aktivitás volt tapasztalható a Budai Arborétumban fejlődő tövek esetében.

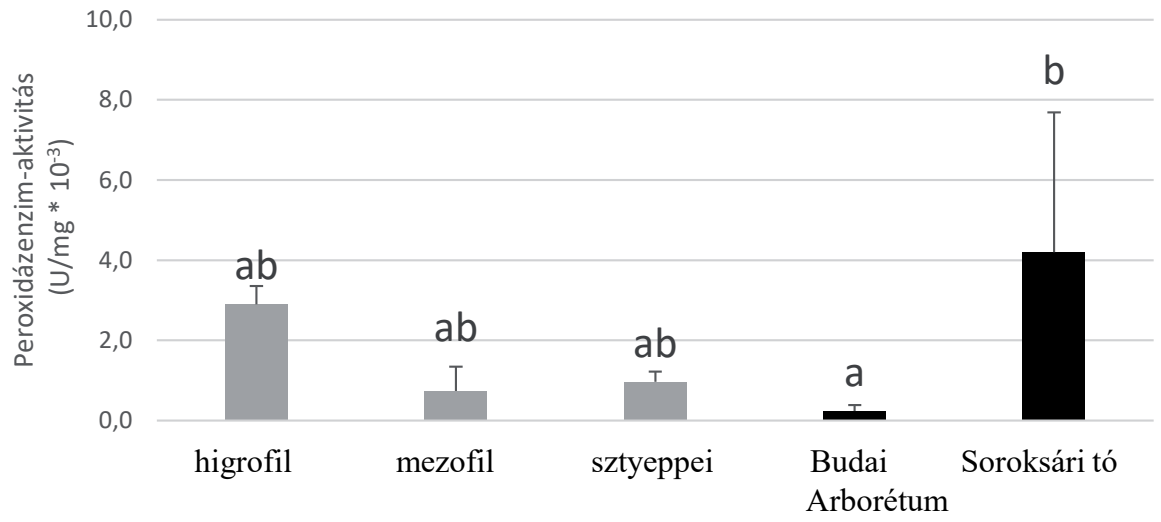

4. ábra. A peroxidázenzim-aktivitás összesített értékei állományonként. A szóráspálcikák \pm 1 szórást mutatnak, az eltérő kisbetűk az oszlopok felett szignifikáns különbséget jeleznek $(\mathrm{p}<0,05)$. Fig. 4. The cumulative values of peroxidase enzyme activity in the different habitats. Error bars show \pm 1 SD, different lower case letters above columns indicate significant difference $(p<0.05)$.

\section{Megvitatás}

Két év tapasztalata alapján elmondható, hogy az ex situ kísérlet az óriás útifü esetében sikeres volt, de a telepített állományok gondos figyelemmel kísérése, monitorozása szükséges ahhoz, hogy a faj számára optimális ex situ feltételeket pontosítsuk, és ehhez további évek eredményei szükségesek. Összesen öt állományt hoztunk létre, 308 db egyed kiültetésével. A különböző vízellátottságú lápréti állományok közül 2016-ban a mezofil állomány, míg 2017-ben a sztyeppei állomány mutatott nagyobb növekményeket. Ezek az eredmények azonban még csak a vizsgálat kezdeti szakaszáról szólnak. A túlélési arány a mezofil és sztyeppei állományban hasonló volt, de előbbi 69\%-os értékkel kissé magasabb volt a sztyeppeihez (64\%) képest. Ugyancsak a mezofil állományban volt a legalacsonyabb a peroxidázenzimaktivitás. Eddigi vizsgálataink eredményei arra engednek következtetni, hogy a 
hazai irodalmi adatokkal összhangban (VIDÉKI és MÁTÉ 2003) a faj számára optimális feltételeket a mezofil állomány, azaz a közepes vízellátottságú, gyengén baziklin, alacsony sótartalmú, oligotróf termőhely nyújtja. Ez az eredmény eltér a SCHNEIDER-BINDER (1978) által említett, jellemzően pangóvizes előfordulástól. Feltehetően a hazai populációk, amelyekből a telepítéshez használt magok származtak, már szárazabb termőhelyi viszonyokhoz adaptálódtak.

A kékperjésbe telepített állományok közül a higrofil élőhelyen mértük a legmagasabb peroxidázenzim-aktivitást, és itt a mortalitás is jelentős volt. A stressztényezők feltételezhetően itt voltak a legerősebbek - elsősorban a magas vízállás lehetett a faj számára szuboptimális - így kimondhatjuk, hogy ez az élőhely a faj számára kedvezőtlenebb. A higrofil állomány talajának víztelítettsége azonban évről évre változhat, ami eltérő viselkedést válthat ki a populációból. A sztyeppei állomány élőhelyi sajátosságai hasonlítanak leginkább a Táborfalvai Lő- és Gyakorlótérhez. A Solidago és Symphyotrichum fajok jelenléte a sztyeppei jellegủ kékperjés és a táborfalvai természetes állomány élőhelyén egyaránt problematikus, mivel versenytársat jelentenek az útifü számára. Ugyanakkor a sztyeppei állomány esetén tapasztalt viszonylag magas túlélési arányból arra lehet következtetni, hogy az óriás útifü zavarástürése viszonylag jó, és kompetíciós ereje is relatíve kielégítő. Mindazonáltal a kompetíció feltételezhetően negatívan hat a generatív stádium megjelenésére.

A Soroksári Botanikus Kert tava melletti és a Budai Arborétum évelöágyi egyedei a 2016-os évben minden morfometriai paraméter tekintetében elkülönültek a három lápréti állománytól. A paraméterek többségében a Budai Arborétum tövei értek el nagyobb értékeket. A 2017-es évben már voltak egyező értékek a lápréti állományokkal, de összegezve elmondható, hogy mind a növekményben, mind pedig a virágzatok megjelenésében, számában a Budai Arborétumban elültetett tövek teljesítettek a legjobban. Ez az állomány kapja a legintenzívebb kertészeti kezelést (rendszeres öntözés, gyomlálás), és a kompetíció hiányában az erőforrás-allokáció zavartalan. A peroxidázenzim-aktivitás alacsony értéke szintén azt mutatta, hogy alacsony stresszhatásnak voltak kitéve az egyedek. A kiültetés évében már bekövetkező virágzást tapasztalva fontos megállapítás volt, hogy nem mindig szükséges több év vegetatív stádium ahhoz, hogy generatív fázisba lépjenek az egyedek. Feltételezésünk szerint a kompetíciós hatás, ami a természeteshez közeli állományokban jelentkezett, gátolta a generatív stádiumba lépést. Vélhetően ezzel magyarázható a virágzás elmaradása a két év során. Másrészt nem zárható ki, hogy a tápanyag-ellátottság és a talajvíz mélysége is befolyásolhatták a generatív fázis elmaradását a láprétre kitelepített állományokban. További vizsgálatok szükségesek a reproduktív fázis előmozdításának érdekében, és a szaporodóképes állományok biztosítása céljából. 


\section{Köszönetnyilvánítás}

Tisztelettel köszönjük a Duna-Ipoly Nemzeti Park Igazgatóság munkatársainak: Bérces Sándornak, Baranyai Zsoltnak, Halász Antalnak és Verő Györgynek a munkáját, akik segítségünkre voltak a területek bejárásánál, a mintavételezésnél és az engedélyeztetési eljárás lefolytatásánál. Köszönetünket fejezzük ki a munka létrejöttéhez nyújtott segítségükért a Szent István Egyetem Kertészettudományi Kara Dísznövénytermesztési és Dendrológiai Tanszék, valamint a Növénytani Tanszék és Soroksári Botanikus Kert munkatársainak, akik a növények fenntartási tevékenységében és a laboratóriumi munkában segítettek. Megköszönjük dr. Ladányi Márta áldozatos munkáját a statisztikai értékelésben nyújtott segítségéért.

\section{Irodalomjegyzék}

13/2001. (V. 9.) KöM rendelet - a védett és a fokozottan védett növény- és állatfajokról, a fokozottan védett barlangok köréről, valamint az Európai Közösségben természetvédelmi szempontból jelentős növény- és állatfajok közzétételéről. https://net.jogtar.hu/jogszabaly?docid $=\mathrm{A} 0100013 . \mathrm{KOM}$ (Utolsó letöltés: 2019. szeptember 16.)

ASADA K. 1992: Ascorbate peroxidase - a hydrogen-peroxid scavenging enzyme in plants. Minireview. Physiologia Plantarum 85: 235-241. https://doi.org/10.1034/j.1399-3054.1992.850216.x

BoRHIDI A. 1993: A magyar flóra szociális magatartás típusai, természetességi és relatív ökológiai értékszámai. Janus Pannonius Tudományegyetem, Pécs, 93 pp.

BotTA-Dukát Z., DancZa I. 2004: Magas aranyvessző (Solidago gigantea Ait.) és kanadai aranyvessző (Solidago canadensis L.). In: MinÁLY B., BotTA-DuKÁT Z. (szerk.): Biológiai inváziók Magyarországon: Özönnövények. TermészetBÚVÁR Alapítvány Kiadó, Budapest, pp. 293-318.

European Commission Dg Environment 2013: Interpretation Manual of European Union Habitats - EUR28. http://ec.europa.eu/environment/nature/legislation/habitatsdirective/ docs/Int_Manual_EU28.pdf (Utolsó letöltés: 2019. szeptember 16.)

FAR KAS S. 1990: Tolna megye védett növényei. Babits Mihály Művelödési Központ, Szekszárd, 97 pp.

FARKAS S. (szerk.) 1999: Magyarország védett növényei. Mezőgazda Kiadó, Budapest, 183 pp.

FRASER L., KEDDY P. (eds) 2005: The world's largest wetlands: ecology and conservation. Cambridge University Press, Cambridge, pp. 34-35. https://doi.org/10.1017/CBO9780511542091

Horváth F., Dobolyi K., Morschhauer T., Lökös L., Karas L., Szerdahelyi T. 1995: FLÓRA adatbázis 1.2. Taxon-lista és attribútum-állomány. Flóra Munkacsoport, MTA Ökológiai és Botanikai Kutatóintézete és MTM Növénytár, Vácrátót - Budapest, 252 pp.

HöHN M. (szerk.) 2013: 50 éves a Soroksári Botanikus Kert. Budapesti Corvinus Egyetem, Növénytani Tanszék és Soroksári Botanikus Kert, Budapest.

KIRÁLY G. (szerk.) 2009: Új magyar füvészkönyv. Magyarország hajtásos növényei. Határozókulcsok. Aggteleki Nemzeti Park Igazgatóság, Jósvafő, 394 pp.

KovÁcs Zs. 2017: A fokozottan védett óriás útifü (Plantago maxima Juss.) ex-situ fenntartása gyűjteményes kertekben és alkalmazási lehetőségei dísznövényként. Diplomamunka, Szent István Egyetem, Budapest, 56 pp.

KovÁcs Zs., BARABÁs S., HöHN M. 2018: Az óriás útifü (Plantago maxima Juss. ex Jacq.) csírázásbiológiai vizsgálatai. Botanikai Közlemények 105(2): 243-252. https://doi.org/10.17716/ botkozlem.2018.105.2.243 
LÁNG F. (szerk.) 2002: Növényélettan. A növényi anyagcsere I. ELTE Eötvös Kiadó, Budapest, 998 pp. MolnÁr-Baji É. (szerk.) 2013: Turjánvidék: Az Alföld rejtett kincse. WWF Magazin (2): 6-9.

Reig P., Shiao T., Gassert F. 2013: Aqueduct water risk framework. Working paper. Washington DC: World Resources Institute. http://www.wri.org/publication/aqueduct-water-risk-framework (Utolsó letöltés: 2019. szeptember 16.)

SCHNeIDER-BINDER, E. 1978: Zur Verbreitung, Ökologie und Zönologie des Riesenwegerichs (Plantago maxima Juss.). Stud. Comm. Muz. Brukenthal 22: 137-172.

Simon T. 2000: A magyarországi edényes flóra határozója. Nemzeti Tankönyvkiadó, Budapest, $422 \mathrm{pp}$.

Soó R. 1968: A magyar flóra és vegetáció rendszertani-növényföldrajzi kézikönyve III. Akadémiai Kiadó, Budapest, 506 pp.

Tzonev R., Karakiev T. 2007: Plantago maxima (Plantaginaceae): a relict species new for the Bulgarian flora. Phytologia Balcanica 13(3): 347-350.

VidÉKi R., MáTÉ A. 2003: Az óriás útifü (Plantago maxima Juss.) Magyarországon. Flora Pannonica 1(1): 94-107.

\section{Ex situ protection of the giant plantain (Plantago maxima Juss. ex Jacq.) II. Habitat preference studies}

\section{Zs. KOVÁCS ${ }^{1}$, S. BARABÁS ${ }^{2}$, P. CSONTOS ${ }^{3}$, M. HÖHN ${ }^{4}$ and P. HONFI ${ }^{5}$}

${ }^{1,4}$ Szent István University, Department of Botany and Soroksár Botanical Garden, Villányi út 29-43, H-1118 Budapest, Hungary; ${ }^{1}$ zsofia.kovacs42@gmail.com,

${ }^{4}$ Hohn.Maria@kertk.szie.hu

${ }^{2}$ Department of Terrestrial Ecology, Centre for Ecological Research, Institute of Ecology and Botany, Alkotmány u. 2-4, H-2163 Vácrátót, Hungary; kanyisa@freemail.hu

${ }^{3}$ Centre for Agricultural Research, Institute for Soil Science and Agricultural Chemistry

Department of Soil Biology, Herman Ottó út 15, H-1022 Budapest, Hungary; csontos.peter@agrar.mta.hu

${ }^{5}$ Szent István University, Department of Floriculture and Dendrology, Villányi út 29-43, H-1118 Budapest, Hungary; Honfi.Peter@kertk.szie.hu

Accepted: 16 September 2019

Key words: conservation biology, ex situ, morphometry, peroxidase enzyme activity, species conservation.

The research reported here is a continuation of our previous germination study on the giant plantain (Plantago maxima Juss. ex Jacq.) aiming at the species ex situ conservation. Seedlings obtained from the germination tests were used for the establishment of ex situ stands. In order to understand the species' habitat preferences, ex situ stands were planted in three different habitat types according 
to soil water regime: a hygrophilous, a mesophilous and a steppic habitat. These ex situ stands (starting with 100 seedlings each) were set up in a fen meadow in the Soroksár Botanical Garden (Budapest, Hungary), while two additional, very small ex situ stands were created and maintained by horticultural management including regular weed control and watering. Morphometric measurements were used to follow the development of plants in these ex situ stands. In 2017, we also assessed plant survival rate. In the natural fen meadow, we recorded the species composition to characterize the community. To check the physiological status of the individuals in different habitats, we measured peroxidase enzyme activities in individuals sampled from different habitat types. According to our results, mesophilous fen meadow conditions seem to be the most appropriate for the growth and development of the species. Here plants developed properly, the measured peroxidase enzyme activity was low and the survival rate was the highest. Individuals in the other two stands, from the hygrophilous and xeromesophilous (steppic) sites, were significantly less developed. Those plants which were under horticultural care, attained the generative phase in the year of relocation, while those stands established on the fen meadow did not flower during the two-year-long study. Based on morphometrical measurements, plants growing under horticultural management reached the greatest growth. 